\title{
Enhancing resilience of at-risk social groups to climate change in two contrasting ecosystems in the semi-arid Far North Region Cameroon
}

Hamza Moluh Njoya ( $\sim$ Hamza.Moluh-Njoya@zalf.de)

Leibniz Centre for Agricultural Landscape Research: Leibniz-Zentrum fur Agrarlandschaftsforschung (ZALF) e V https://orcid.org/0000-0002-5067-2871

\section{Shibire Bekele Eshetu}

Leibniz Centre for Agricultural Landscape Research (ZALF): Leibniz-Zentrum fur

Agrarlandschaftsforschung (ZALF) e V

Haji Athumani Msangi

Sokoine University of Agriculture Department of Agricultural Economics and Agribusiness

Herve Alain Napi Wouapi

Universite de Dschang Faculte d'Agronomique et des Sciences Agricoles

Katharina Loehr

Leibniz Centre for Agricultural Landscape Research: Leibniz-Zentrum fur Agrarlandschaftsforschung (ZALF) e V

\section{Stefan Sieber}

Leibniz Centre for Agricultural Landscape Research: Leibniz-Zentrum fur Agrarlandschaftsforschung (ZALF) e V

\section{Research Article}

Keywords: Sustainable livelihoods-agriculture, resilience, social vulnerability, land use practices, climate change hotspots

Posted Date: February 1st, 2022

DOI: https://doi.org/10.21203/rs.3.rs-1273273/v1

License: (1) This work is licensed under a Creative Commons Attribution 4.0 International License. Read Full License 


\section{Abstract}

Climate change and variability contribute to exacerbating poverty and social tensions in poor countries. This research examines the underlying processes that contribute to a shared understanding of the socioecological resilience of upland and floodplain farming systems in the Far North Region of Cameroon. Built on community-based data and 28 key informant interviews to characterize farmers' livelihoods, including implications of (non) climate factors on the latter, the research uses qualitative content analysis for data validation and analysis. The study reveals that the majority of farmers are most concerned about erratic rains and false starts, two major constraints for farm output. Further, the breakup of social capital as community members scatter in desperate search of alternative livelihood options is another factor. Overall, the resilience of farming communities in the studied areas is largely undermined by exposure to water- and vector-borne diseases, inadequate village infrastructure, lack of timely access to quality agroinput, seasonal weather forecasts, and institutional support. Food shortages are a potential consequence. Further, over-reliance on grazing land and water leaves herders with little or no viable options, just a narrow window to move their livestock to the neighbouring Chad Republic in a quest for fodder - a costly and counterproductive option. Finally, the findings suggest effectual coping strategies and a culture of adaptive management, including the establishment of relevant institutions to lessen vulnerability and foreseeable threats to food security in the semiarid climate change hotspots of the Far North region Cameroon.

\section{Introduction}

The impacts of climate change are already being felt globally. Direct human impacts include decreased agriculture yields, increased flooding, more droughts, severe storms, threats to water and energy supplies in remote regions, and the spread of epidemics. Climate change and variability contribute to the worsening of poverty and social tensions in poor countries and developing countries. Due to their low socioeconomic resilience, developing countries are significantly affected by climatic stressors (Dixon, Smith, and Guill 2003). This is exemplified in semiarid and arid countries in Sub-Saharan Africa (SSA), which is considered to be particularly vulnerable to climate variability and change. According to Kotir (2011), semiarid areas in SSA expected to be especially sensitive to climate change and are in need of practical means to reducing their vulnerability to the effects of climate change. In line with the above, the Intergovernmental Panel on Climate Change (IPCC 2007), in their report predicting the effects of global warming by geographical regions, stresses that many regions in the Sahel were likely to experience falling yields under rain-fed agriculture of up to $50 \%$ by 2100 . These projections, observations, and estimates for the future well reflect the current situation in the Far North semiarid region of Cameroon. It also contributes to an understanding of the scale of the problem, hence constituting a rationale for preventative efforts (MINEP 2009).

However, the lack of progress in mitigation, through reduced emissions, is part of the reason for a shift in focus toward adaptation, a concept now embodied by both the development aid and climate change communities (Eriksen et al 2021; Schipper 2020). Nonetheless, the focus within adaptation discourse is 
chiefly on impacts and less on the underlying processes that contribute to vulnerability (Schipper 2007) and the outcomes that ought to shape responses to climatic variability and change (Kelly and Adger 2000). Other strands of knowledge highlight the link between vulnerability and sustainability through coupled human-environment systems in which the concept of resilience plays a key role in determining the system's ability to cope or respond to environmental excesses (Turner li 2010). Thus, the concept of resilience influences a variety of interdisciplinary studies, often aiming to improve adaptive capacity (Turner li 2010). Existing links between environmental and social resilience are exceptionally clear in social systems that depend on a narrow range of natural resources (Adger 2006). Therefore, examining resilience in the context of resource poor dependents in developing countries can make important and new contributions to furthering research and scholarship in climate change adaptation since it is expected that the poorest groups will be most affected by continuing climatic variability (Turner et al 2003). These groups include small-scale farmers of the Far North semiarid region of Cameroon, who are located in areas where Pedi floodplains, mountains, and sloping land abound. As a result, poverty rates among the communities in this region are higher than in the southern areas of the country, where populations have disproportionately benefited from Cameroon's poverty reduction strategy and economic growth (ECAM4 2014). While often viewed as "backwards" and dependent on external intervention and international relief, semiarid small-scale farmers in the Far North semiarid region of Cameroon have, in many cases, developed highly complex agrarian systems that are well suited to the specific ecological setting and natural resources upon which they depend. Further, these populations often must deal with numerous external factors that put pressure on the natural resources that sustain their livelihoods, including government resettlement programmes and land laws. Concurrently, Tidze et al (2016) stress that firewood and charcoal appear to be the main sources of energy used by approximately $80 \%$ of households in the semi-arid region of Cameroon, essentially for cooking. Such heavy reliance on wood fuel is one of the major roots of deforestation. Processes of deforestation are also linked to reductions in soil moisture and overall soil fertility through increased erosion and decreases in soil organic material, which result in drought-prone conditions (R. P. C. Morgan 2009). The combined effects resulting from soil erosion is a net loss of productivity, further restricting farmers' choice of crops to grow and can increase expenditures on inputs (R. P. C. Morgan 2009). Thus, soil erosion constitutes a significant factor in determining both the environmental resilience of the farming system through effects on soil fertility, soil moisture, and other biological factors, as well as social resilience through effects on the productivity of the farming system, which has implications for land use patterns and livelihood strategies.

This research addresses the issue of vulnerability and resilience with regard to climate change in upland and floodplain areas of the semi-arid Far North Region of Cameroon, viewing vulnerability and resilience as determinants of adaptive capacity. The overall objective of this research is to investigate the underlying factors that contribute to an understanding of the social and environmental resilience of upland and flood plain farming systems in the context of environmental change. Specifically the analysis is responding to the question of how do we identify and explain the multiple underlying political, socioeconomic, and environmental forces that influence the ways in which resource-poor dependents in 
mountain and floodplain ecosystems in the Far North semiarid area of Cameroon are exposed and sensitive to climate as well as their capacities to adapt to changing conditions?

\section{Materials And Methods}

\subsection{Description of the Study Area}

This study focuses on selected areas in the Far North semi-arid region of Cameroon. Farming systems at the chosen sites are diverse, ranging from pastoral-dominated systems through strongly interacting croplivestock enterprises to crop-dominated systems where livestock were decimated by diseases. This diversity offers an opportunity to identify different types of "best fit" adaptation strategies, each matching the specific agro-ecological niches named above. The study is based on ethnographic research focusing on one mountain village (Mayo Tsanaga Division) and one village located in the floodplain (Logone and Chari Division) of the Far North semi-arid region of Cameroon, where we relied on collaboration from the Centre for Environment and Development Studies (CEDC) and the National Polytechnic School (NPS) to collate and process all necessary data. The Mayo Tsanaga division comprises seven councils classified as "Mandara" mountainous, while the Logone-and-Chari division has 10 councils classified as "flooded floodplain." The "Mandara" mountains are inhabited by three ethnic groups (Mafa, Mofou, and Kapsiki), while the floodplain is inhabited by three major ethnic groups (Mouzgoum, Kotoko, and Arabes Choas). The majority of the population in the region lives far below the official poverty line (ECAM4 2014). The study took place in one "Mandara" mountainous council (Mayo-Moskota) and one floodplain council (Logone Birni), with two villages (Tilde and Zeleved) identified for study. Villages were selected based on differences in institutional arrangements as regards natural resource management, mainly determined by traditional, informal institutions and land use policies. Farming systems in the villages were similar in composition and crop production forms a major part of livelihoods in both villages, thus facilitating intervillage comparisons.

\subsection{Data Types and Sources}

For this study, qualitative data was collected three in complementary approaches between August 2020 and February 2021: Individual interviews with farmers, Focus groups with farmers, Individual expert interviews with government officials. Table 2 provides an overview of the different methods, number of interviews, locations, and selection criteria. Qualitative data is further complemented with secondary data from a literature review. The study draws on ethnographic research, in which the adaptive role of subsistence farmers, the at-risk 'target' communities, is examined.

To this effect, a vulnerability and resilience to climate change assessment, complemented by a participatory risk ranking (among small-scale farmers), was conducted with the irrigation-dependent and rainfed agricultural community of the villages of Zeleved and Tilde. The goal of these community-based data collection methods was to identify and explain socioeconomic, environmental, and politicalinstitutional dynamics of vulnerability, thus contributing to an understanding of the ways at-risk groups 
are exposed and sensitive to climate-related conditions and their capacities to adapt under changing climate and other conditions.

The research technique used did not assume to know a priori the climate factors that matter to the Zeleved and Tilde communities' livelihoods or the determinants of vulnerability. Rather, these were identified over the course of the fieldwork based primarily on data provided by Zeleved and Tilde community members themselves. Most primary data were derived from a total of 28 semi structured in depth interviews from the 2 villages, whereby 14 semi-structured in-depth interviews with 7 females and 7 males were collected in each village. According to (Ziervogel and Taylor, 2008), the use of semi-structured interviews allows for an in-depth understanding of critical issues across a range of research contexts by guiding conversations along themes of interest to the researcher. Additionally, four focus groups discussions of 15 people each in each village, with a mix of older and younger people, men and women, were conducted with community-based organisations (CBOs) from the selected villages and their environs. Focus groups discussions were employed to scrutinize interactions between community members and other aspects of vulnerability that turned out to become evident in the community dynamic. (D. L. Morgan 1996) refers to this as an effect of synergism. Communities members involved in focus groups discussions were selected using case sampling methods to identify group leaders and members who were representative of the population to obtain a categorization of Zeleved and Tilde communities. The focus groups discussions were conducted with strict compliance to all relevant COVID-19 pandemic containment measures.

Members from the communities under study who were engaged in subsistence farming, as well as women and the elderly, were included in order to gain insight into different experiences within the communities. In order to minimise biases in the answers from the smallholder (with regard to climate factors that intersect with their livelihoods), the questionnaire survey was passed on and exploited after each respondent was asked to do the following using local terminology:

i. Evaluate the current situation, for example: income source, field size, number of animals, etc;

ii. Next, describe the major changes to these assets over the last 30 years, if any.

iii. Finally, assess the main drivers/roots of these changes, if any.

This means that no explicit reference to the focus on climate factors was initially presented to the respondents. It is only at the end of the interviews and focus group discussions that the respondents were asked to assess their perception of climate variability and change along with the perceived impacts of this on a range of livelihood parameters (These include: (i) household characteristics, (i) who and what is/are vulnerable, (iii) vulnerability to what stresses or exposures-sensitivities through for e.g. investigation of recurring episodes of external environmental pressure over the past 30 years, and (iv) what capacities exist to adapt to changing conditions). Climate variability and change was viewed in the context of these and other conditions. To familiarise the respondents in adjusting the abstract conceptual language associated with climate variability and change, the respondents were taken through a little exercise meant to find appropriate meaning in local terminology of some of the key concepts used in the 
field of climate change. Table 1 provides an overview of some of the climate change concept definitions and their equivalence in the Arabe Choa and Mafa dialects.

Table 1

Equivalence to some of the key concepts of climate change adaption in Arabe Choa and Mafa dialects

\begin{tabular}{|lll|}
\hline Key concepts & $\begin{array}{l}\text { Dialect of Arabe } \\
\text { Choa }\end{array}$ & Mafa dialect \\
\hline Vulnerability & da if & Ndi te dalali \\
\hline adaptation & walafa & skwi nwoudi tepa a va \\
\hline Social vulnerability & pauvreté & Ndji te dalali a ndohi télé \\
\hline $\begin{array}{l}\text { Climate variability and } \\
\text { change }\end{array}$ & khayirine al djao & sem Mana ngodeva anvi anvi \\
$\begin{array}{l}\text { Indigenous climate } \\
\text { forecasting }\end{array}$ & $\begin{array}{l}\text { min al djahi } \\
\text { guiddam }\end{array}$ & $\begin{array}{l}\text { nhirgued a skwi Man a vama Man ka guia a Mana } \\
\text { sem ngode va an vi }\end{array}$ \\
\hline $\begin{array}{l}\text { Soothsayer or } \\
\text { 'rainmakers' }\end{array}$ & Kharif & ndohi n'guiyam \\
\hline $\begin{array}{l}\text { Coping strategy: } \\
\text { wassifa kef }\end{array}$ & maya Man ka guia a nchinde skwi nwoudi tepa \\
\hline Adaptive capacity & tandar tiwalif & woudi gui skwi Man ka de tepa \\
\hline
\end{tabular}

It was useful to take advantage of the community-based approach in this way by engaging Zeleved and Tilde communities members as necessary sources of information regarding the circumstances to which they are exposed, along with how people there are sensitive, the adaptive strategies they use, and the conditions that act either as a barrier or catalyst to these strategies.

Through these interactive exchanges, data on the experience of vulnerability by dwellers engaged in subsistence agriculture, livestock, and fishery were gathered. Information on farming techniques, fishing and livestock including the pressures on these means of living and the ways for prevailing over these stresses was compiled.

Key informants included staff representing regional and national governmental agencies (mainly technical ministries whose sectors of activities intersect with climate change adaptation, like the meteorological service, etc.), NGOs, and other international organisations. They were selected based on their expertise and/or experience with the ecosystem peculiarities of the Far North semiarid region of Cameroon. Table 2 below summarises the research techniques employed, including the issues that were discussed. 
Table 2

Summary of the research techniques applied

\begin{tabular}{|c|c|c|c|c|}
\hline \multirow{2}{*}{$\begin{array}{l}\text { Research } \\
\text { techniques }\end{array}$} & \multicolumn{4}{|l|}{ Data description } \\
\hline & Themes covered & $\begin{array}{l}\text { Data } \\
\text { acquisition } \\
\text { time }\end{array}$ & $\begin{array}{l}\text { Temporal } \\
\text { span to cover }\end{array}$ & $\begin{array}{l}\text { Measurable } \\
\text { density }\end{array}$ \\
\hline \multirow[t]{2}{*}{$\begin{array}{l}\text { Participant } \\
\text { observation }\end{array}$} & \multirow{2}{*}{$\begin{array}{l}\text { Everyday life, Livelihood } \\
\text { diversification, Household } \\
\text { composition, income and } \\
\text { practices, Role of agriculture, } \\
\text { Cattle ownership }\end{array}$} & $\begin{array}{l}\text { August } \\
2020-\end{array}$ & \multirow[t]{2}{*}{$\begin{array}{l}\text { Contemporary } \\
\text { issues }\end{array}$} & \multirow{2}{*}{$\begin{array}{l}\text { Constant } \\
\text { presence in } \\
\text { Zeleved and } \\
\text { Tilde villages } \\
\text { and its } \\
\text { vicinity }\end{array}$} \\
\hline & & $\begin{array}{l}\text { February } \\
2021\end{array}$ & & \\
\hline \multirow{3}{*}{$\begin{array}{l}\text { Semi- } \\
\text { structured } \\
\text { interviews } \\
\text { (with the help } \\
\text { of a } \\
\text { questionnaire } \\
\text { survey) }\end{array}$} & \multirow{2}{*}{$\begin{array}{l}\text { Biophysical, agriculture and } \\
\text { livelihood changes over time, } \\
\text { Drivers/roots of changes, } \\
\text { Adaptive response to changes } \\
\text { over time, Climate perceptions, } \\
\text { Household composition, }\end{array}$} & $\begin{array}{l}\text { August } \\
2020-\end{array}$ & \multirow{3}{*}{$\begin{array}{l}\text { Past } 30 \text { years } \\
\text { Contemporary } \\
\text { issues }\end{array}$} & 28 conducted \\
\hline & & \multirow[t]{2}{*}{$\begin{array}{l}\text { February } \\
2021\end{array}$} & & $\begin{array}{l}\text { differentiated } \\
\text { with respect } \\
\text { to age, } \\
\text { gender, social } \\
\text { status, }\end{array}$ \\
\hline & $\begin{array}{l}\text { income and practices, Historical } \\
\text { developments/extreme events, } \\
\text { Climate perceptions }\end{array}$ & & & $\begin{array}{l}\text { ethnicity and } \\
\text { place of } \\
\text { residence }\end{array}$ \\
\hline \multirow[t]{3}{*}{$\begin{array}{l}\text { Focus group } \\
\text { interviews }\end{array}$} & $\begin{array}{l}\text { Economic, biophysical changes } \\
\text { over time, }\end{array}$ & $\begin{array}{l}\text { August } \\
2020-\end{array}$ & \multirow{3}{*}{$\begin{array}{l}\text { Past } 30 \text { years } \\
\text { Contemporary } \\
\text { issues }\end{array}$} & $\begin{array}{l}8 \text { FGD of } 15 \\
\text { people each }\end{array}$ \\
\hline & \multirow{2}{*}{$\begin{array}{l}\text { Drivers/roots of change, Adaptive } \\
\text { response to changes over time, } \\
\text { Climate perceptions }\end{array}$} & \multirow{2}{*}{$\begin{array}{l}\text { February } \\
2021\end{array}$} & & $\begin{array}{l}\text { conducted } \\
\text { and }\end{array}$ \\
\hline & & & & $\begin{array}{l}\text { differentiated } \\
\text { with respect } \\
\text { to age, } \\
\text { gender, social } \\
\text { status and } \\
\text { ethnicity }\end{array}$ \\
\hline \multirow[t]{2}{*}{$\begin{array}{l}\text { Key informant } \\
\text { interviews }\end{array}$} & \multirow{2}{*}{$\begin{array}{l}\text { Economic, biophysical changes } \\
\text { over time, Drivers/roots of change, } \\
\text { Adaptive response to changes } \\
\text { over time }\end{array}$} & $\begin{array}{l}\text { August } \\
2020-\end{array}$ & \multirow[t]{2}{*}{$\begin{array}{l}\text { Contemporary } \\
\text { issues }\end{array}$} & \multirow{2}{*}{$\begin{array}{l}14 \text { conducted } \\
\text { among } \\
\text { officials from } \\
\text { government } \\
\text { and non- } \\
\text { governmental } \\
\text { agencies }\end{array}$} \\
\hline & & $\begin{array}{l}\text { February } \\
2021\end{array}$ & & \\
\hline
\end{tabular}

\subsection{Data Analysis}

Qualitative content analysis is used for data analysis. Content analysis is a method that seeks to capture what the interviewees said in as an objective and reliable a way as possible. Qualitative content analysis is an interpretation method for qualitative interviews and other data material that follows content analytical rules and step-by-step models (Kohlbacher 2006). After data collection, the primary purpose of the analysis was to make sense of the themes emerging from ethnographic data, which consisted of 
transcripts of interviews and focus groups, our reflective diary, as well as personal notes and participant observations.

The data collected during the key informant interviews and focus group discussions were captured, grouped, and classified according to the logical order of the specific objectives. Data from secondary sources were presented in tables, figures, and comments, while the data from primary sources were collected in two forms: quantitative and qualitative. These were manually analysed and coded. The data, obtained through semi-structured interviews, focus groups, and key informants, were triangulated with direct observations in the field. This was made possible by the first author's stay in the Zeleved and Tilde communities during the field research.

\section{Results}

\subsection{Exposures to a Changing Environment}

Fieldwork findings reveal that the communities of Zeleved and Tilde experience a variety of biophysical and socioeconomic settings that exacerbate their vulnerability. The outcomes of the vulnerability assessment associated with participatory ranking in the study areas show that the adaptive capacity to climate change among smallholders is weakened by a range of exposure-sensitivities that may be categorized into four main interrelated issues: poor health (with a preponderance of both water and vector-borne diseases), food insecurity, inadequate public goods, and financial insecurity. These exposure-sensibilities heavily constrain the adaptive capacity of Zeleved and Tilde community members, comprising multiple and interrelated processes that act at various scales to form current vulnerabilities at the level of Zeleved and Tilde communities. The worries of the latter are summarised below and ranked based on their severity (Figure 2). Except for a relatively small number of farmers who own a total yield ranging from 5 to $10 \mathrm{ha}$, including livestock holdings, the experience of vulnerability within Zeleved and Tilde communities was found to be somewhat constant, as a large proportion of farmers are smallholders who have little access to material resources that would help them effectively cope with these stresses. Although Figure 2 shows that the four major determinants of vulnerability - food insecurity, poor health, water scarcity, and financial insecurity - are interconnected, this section addresses each one together with the underlying processes and forces that influence the exposure-sensitivity and coping strategies employed by Zeleved and Tilde communities, as well as the factors (including cultural barriers facilitating cholera) impeding their adaptive capacity.

\subsubsection{Food Insecurity}

Before discussing the issue of food insecurity further, it is essential to look into the trends of agricultural production (Figure 3) in the Far North semiarid region since 2011.

The descriptive indicators above show that cereal production across all six divisions comprising the Far North region fluctuates from year to year and follows inter-annual precipitation variation over the same period. Of particular relevance is the fact that the cereal needs of the nearly 4 million residents of the 
entire Far North semiarid region are estimated to be 1,001,653 tons. In 2019/2020, an excess of 89,229.7 tons of cereal production was recorded. In such circumstances, why is food insecurity an issue?

First, it is worth noting that there are variations in average annual precipitation between the six divisions comprising the Far North region. As a result, cereal production is unevenly distributed within the region. This means that communities as a whole experience variable vulnerability, in that certain localities may experience exposure sensitivities to vulnerability more or less acutely.

Second, changes in climatic conditions will not be experienced separately, but together with transformations in the political and socio-economic conditions within which the localities of Zeleved and Tilde function. One example of these changes is population growth. At 2021 growth rates $-2.6 \%-$ the population of the Far North semiarid region, including Zeleved and Tilde, is projected to increase roughly $250 \%$ by 2050 . In the cases of Zeleved and Tilde, population may even increase further as a result of the planned rehabilitation of SEMRY ${ }^{[1]}$ and SODECOTON ${ }^{[2]}$ in the coming years, drawing more population (from within Cameroon and neighboring countries) closer to SODECOTON and SEMRY's agricultural estates.

Finally, food insecurity in Zeleved and Tilde is identified as the second highest anxiety, largely attributed to lower yield, high input costs, and soaring food prices, among others. Many respondents also pointed out that the rains are disappointing them, with a reduction in rainfall and an increase in the frequency of erratic rains and false starts. The situation is made complicated due to the lack of an agro-meteorological service in the Far North Region of Cameroon. Although the region is well known for its fragile ecosystem, the chief unit of the meteorological service of the region reports that none of the meteorological stations in the region are operating. Consequently, seasonal climate forecast information is inaccessible, with data reflecting climate variables (mostly temperature), scarce. Thus agricultural users lack access to actionable weather forecasts.

Furthermore, food insecurity is partly contingent on lower crop yields, in that smallholder farmers usually lack timely access to sufficient quantities of quality agricultural inputs, like fertilizers. In fact, Cameroon imports mineral fertilizers that must be carried from the Port of Douala (the gateway of Cameroon) to Zeleved and Tilde, both more than $1,000 \mathrm{~km}$. This is especially challenging given the poorly developed road infrastructure and high transaction costs, which makes the acquisition of fertilizers by farmers at the right time uncertain.

To find an alternative to the inadequate supply of mineral fertilizers, as many respondents report, farmers have no choice but to acquire NPK directly from Nigeria, a neighboring country. However, in the absence of an effective quality control service, there is no guarantee of the fertilizers' quality or safety. These shortcomings are superimposed on the lack of appropriate agricultural technologies and inadequate institutional support mechanisms to take advantage of the narrow windows of favourable weather conditions that can be used to maximise yields of rice, sorghum, and millet.

\subsubsection{Poor Health}


Poor health is the second concern. Figure 5 shows the physical environment of (a) Zeleved and (b) Tilde, with surfaces suitable for water stagnation, thereby creating a conducive breeding habitat that facilitates the development of Anopheles gambiae female mosquitoes, the principal malaria vector. The most mentioned diseases are vector-borne types, like malaria, and water-borne types, like cholera, which is associated with both floods and droughts. Filariasis (another vector-borne disease that is equally considered to be sensitive to climate change) and bilharzia were also mentioned by the respondents. There are a number of endemic and climate-sensitive diseases with major implications for the adaptive capacity of Zeleved and Tilde community members. In addition, the working environment for rice growers demonstrates that the latter are highly exposed to chemicals. Farmers use fertilizers unprotected, with this exposure putting them at-risk for additional health complications. The multiplier effect being that the latter are superimposed upon the existing weak health system. Such an alarming situation suggests putting in place adaptation measures that lessen human sensitivity and exposure. An option would be to invest more in prophylactic measures against, for example, climate-sensitive vector-borne diseases coupled with improved nutrient access. In other words, a healthier population is more likely to cope with climatic extremes than frail and sick people.

\subsubsection{Access to Potable Water}

Potable water in the villages of Zeleved and Tilde and their vicinities primarily comes from ground water. The fact that only a few wells (Figure 6) are available places a large segment of the population at-risk to water-borne diseases, like cholera, which is now endemic in Zeleved and Tilde. The chief medical staff of the health center of Tilde reported more than 300 cases of cholera in the first ten months of 2019.

\subsubsection{Financial Insecurity}

As farming is now the primary source of income for the majority of Zeleved and Tilde community members, the majority of households report difficulty in earning enough money to meet basic needs (healthcare, education, nutrition, and so on). This is because financial insecurity is not just compounded by some of the aforementioned stresses - including access to potable water, endemic diseases, food insecurity - it is also related to unemployment. In fact, opportunities to move away from subsistence farming are scarce, hence restricting Zeleved and Tilde community members to seize other sources of income. During fieldwork, it also became clear that whilst livestock is an important component of livelihoods in Zeleved and Tilde, with further implications for financial security, declining livestock holdings is exacerbating In addition to the fact that cattle are extremely vulnerable to epidemics, fodder resources are increasingly scarce due to agricultural land expansion that encroaches on grazing, thus leaving herders no choice but to move their cattle to Chad in search of pasture. As a result, having large herds appears problematic, with this situation downplaying the importance of cattle as an "insurance against bad times" even though one well-known Mafa proverb directly says this.

"If you have been told that the cattle of your neighbor was stolen, you will do everything possible from your end to get the ruminant back" 


\subsubsection{Inadequate Village Infrastructure}

The most common modes of transportation and road network, especially during the rainy season, are such that the distances between Zeleved and Tilde to nearby larger markets make transaction costs prohibitively expensive for many farmers. The issue of infrastructure relates more to the lack of fundamental services (e.g., road network, health, and water) and constitutes a currently unfilled climate change adaptation gap, which ought to be prioritised regardless of actual climate change effects or global climate change agreement. While the Republic of Cameroon has adhered to global climate change, the principle of "common but differential responsibility," in light of the magnitude of the constraining climatic and non-climatic stresses currently experienced by small-scale and poor resource-dependent farmers, appears to have become a convenient pretext for the government of Cameroon to ignore its core obligations, which consists of providing the basic social amenities that rural areas equally deserve. To sum up the factors influencing exposure-sensitivity, the coping strategies employed by Zeleved and Tilde communities, including the factors impeding their adaptive capacity, are summarized in Table 3.

Table 3. Synopsis of exposure-sensitivities, coping strategies, and adaptive capacity constraints experienced by Zeleved and Tilde

\begin{tabular}{|lll|}
\hline $\begin{array}{l}\text { Exposure- } \\
\text { sensitivity }\end{array}$ & Coping strategy & Adaptive capacity limits \\
\hline $\begin{array}{l}\text { Poor } \\
\text { health }\end{array}$ & $\begin{array}{l}\text { Consult traditional } \\
\text { healers, use of } \\
\text { traditional } \\
\text { medicines }\end{array}$ & $\begin{array}{l}\text { Low access to financial resources, family size, poor access to } \\
\text { social network, lack of hygiene rules }\end{array}$ \\
\hline $\begin{array}{l}\text { Food } \\
\text { insecurity }\end{array}$ & $\begin{array}{l}\text { Invest in farming, } \\
\text { livestock and/or } \\
\text { fishing }\end{array}$ & $\begin{array}{l}\text { Poor health, lack of labour force, high labour cost, poor access } \\
\text { to social networks }\end{array}$ \\
\hline $\begin{array}{l}\text { Water } \\
\text { scarcity }\end{array}$ & $\begin{array}{l}\text { Walk to lake, pond } \\
\text { to fetch water }\end{array}$ & Limited access to financial capital, decreases in rainfall \\
\hline $\begin{array}{l}\text { Financial } \\
\text { insecurity }\end{array}$ & $\begin{array}{l}\text { Reliance on money } \\
\text { lenders }\end{array}$ & $\begin{array}{l}\text { Strong dependence vis-à-vis loan-sharks, lack of alternative } \\
\text { livelihood options, cultural events, lack of rural dynamics, family } \\
\text { size, and low educational level attainment }\end{array}$ \\
\hline
\end{tabular}

\subsection{Community Developed Adaptive Farming Strategies}

Pockets of drought increase the risk of a poor harvest, constituting a constraint for rural communities (Houssou-Goe 2008). It disrupts agricultural calendars, imposes different lifestyles and gives another vision of the perception of the climate in this environment. The persistence of the climate crisis requires adaptation efforts to decrease the risk and overcome the climate constraint. The field work shows that both communities established new context dependent farming systems to adapt to the current environment; these farming systems aim to increase or at least maintain the current level of production and productivity. This study finds that new farming practices were developed according to the type of the respective ecosystem in both communities. 


\subsubsection{Farming Systems Developed in Mountain Villages (Zeleved)}

The main farming techniques developed in the mountains are terraced cultivation, flat crops, and the installation of dykes. Terraces are anti-erosion devices generally set up on land with very steep slopes. Thus, most farmers in the mountain village (Zeleved) grow crop on terraces. Earth bunds or anti-erosion bulges are structures built in earth. Waterproof, they retain all water and promote maximum infiltration. It should be noted that earthen bunds are only used when conditions do not allow stone structures to be built (Hamza et al, 2019). Figure 7 shows the techniques used in Zeleved village.

\subsubsection{Farming Systems Developed in Plains Villages (Tilde)}

The main techniques developed in Tilde and in the piedmont are ridge cropping, half-moon, and zaï. In the plains, stone bunds were also installed. Among the techniques practiced in the plains and piedmont, the most widely used is the trap and the ridges, as most of the farmers in the area use these. These are planks made in the shape of a bowl to retain water to facilitate good filtration.

The half-moon is an agricultural technique aimed at clearing the earth from ponds of a few meters, to form basins (or mounds) of a semi-circle in the shape of half-moons opened using a pick, pickaxe, and shovel. Half-moons and zaï aim to concentrate rainwater, reduce runoff and to cultivate on crusted land. Crops with developed roots, like beans and peanuts, can be sown on bunds, while crops with poorly developed roots, like maize, millet, and sorghum, can be sown in half moon (Sawadogo 2011; Hamza et al 2019). This technique is one way to address the issue of aggressive climate change and restoring degraded soil, which is an urgent local matter. Figure 8 illustrates the $(\mathrm{g})$ plank and $(\mathrm{h})$ half-moon techniques.

Other techniques, including the crop association, zaï, agroforestry, the use of human urine, and the use of livestock waste, are also identified. Figures 9 give an example of $(\mathrm{I})$ crop association of crops and $(\mathrm{J})$ the use of livestock waste.

[1] SEMRY (Rice Development Authority) is a state-owned company which develops rice cultivation in the semiarid Far North region of Cameroon, (rice cultivation through irrigation by gravity) [2] SODECOTOM (Cotton Development Authority) is also a state-owned company which develops cotton cultivation in the semiarid Far North Region of Cameroon.

\section{Discussion}

As adaptation occurs locally, it is appropriate to measure the stringency of climate change impacts on atrisk groups through a detailed study conducted in Zeleved and Tilde villages in the semiarid Far North Region of Cameroon. This analysis helps to document the conditions that affect the livelihoods and lives of at risk communities in the study areas, tracing the underlying processes that contribute to the 
community's exposure-sensitivities, featuring the ways in which the community has coped with the stressors, as well as evaluating the constraints and opportunities for better coping with environmental changes. Given that the processes of vulnerability identified in this study may have several implications for champion activities intended to foster effectual adaptation to future changes in climate, this section elaborates further on a couple of issues.

While interacting with farmers, it became clear that their major concerns with regard to the impacts of climate variability and change are about the management of climate-induced risk. The needs of smallscale farmers can be summarized in two essential questions:

What are the risks if we sow earlier?

What are the risks if a dry spell occurred in the middle of the growing period?

Carberry et al (2004) back up the worries expressed by farmers when arguing that the quantification of climate-induced risk and its management can greatly support risk-averse farmers' decision making processes and, hence, enhance the adoption of more sustainable and productive farming practices. Small-scale farmers in the study area represent an irrigation-dependent (for rice and vegetable gardening) as well as a rainfed (for millet, sorghum, corn, Niebe, groundnuts, and, to a lesser extent, rice) community. Both types of agriculture remain the mainstay of food and feed production in Zeleved and Tilde. However, as the fieldwork reveals, the outcomes of the lack of low production of rainfed agriculture reinforce each other, leading to poverty traps and increased vulnerability to climatic shocks. Nevertheless, in spite of the encouraging signs of greater commitment expressed by the Cameroon government to boost both rainfed and irrigated agriculture in the Far North semiarid environment, there is one essential feature of this sector that cannot be overlooked. Rainfall variability (mainly in the form of erratic rains and false starts), both within and between seasons, is an underlying risk factor, lending uncertainty to farm-level production, including for potential of science (through breeding and biotechnology) and technology conceived to improve crops and/or implement innovative adaptation agricultural practices, such as integrated soil fertility and livestock management. It should be noted that this uncertainty discourages the adoption of improved farming practices that can turn into adaptation options. In addition, during the interviews, small-scale farmers show that they often overestimate the negative impacts of climate variability and change. Cooper et al (2008) note that the consequence of this is that farmers demonstrate an understandable reluctance to invest in potentially more sustainable, productive, and economically rewarding practices when the returns to investment appear so unpredictable from season to season. Washington et al (2006) reason that the response to the constraints of climate-induced production risk and the predicted change in nature of such risk in the future lies in the 'twin pillars' of adaptation (shortand medium-term strategies) to climate variability and change.

The shorter term would mean that small-scale farmers in Zeleved and Tilde get assistance in building their livelihood resilience by coping better with current rainfall variability as a prerequisite to adapting to future climate change. The fact that greater resilience allows farmers a wider range of adaptation options in the future is true. However, local context specificity, as per Zeleved and Tilde, suggests that more 
consideration must be given to the already substantial current season-to-season weather ranges and the extent to which these ranges will affect the future. This is where the importance of agro meteorological services and a national climate change observatory become obvious. With the help of these specialized units, the extent that small scale farmers in the Far North semiarid region of Cameroon will experience conditions under progressive climate variability and change that they are not already experiencing today can be explored. The illustration of this can transpire through analysis of longer time-scale relative to long-term daily weather data in order to provide more accurate information with regard to the length of growing period under temperature rise.

The findings presented illustrate that concerns about the effects of climate variability and change on rural societies in the Far North semiarid region are justified: climate changes are happening and they disturb activities that depend on the natural environment. Changes in temperature and rainfall variability are already observed by affected communities. These changes in climate could have several implications for the exposure-sensitivities identified in the vulnerability assessment of the communities of Zeleved and Tilde. Increases in temperature and rainfall variability result in increased stresses on crop production and food security. Similarly, Kotir (2011) contend that increases in inter-annual variability, dry spells, as well as periods of flooding and infestation will affect crop productivity and could result in crop failure. There is the fact that none of the farmers and extension workers in the area of Zeleved and Tilde have ever been introduced to, or used, seasonal climate forecasts. However, we argue that more efficient dissemination of climate outlook information may have the potential to help prevent crop losses, among other examples. Such a situation suggests that extension agents should be trained in the use, interpretation, and limitations of forecasts. This also requires a strong science-practice interface (i.e. a functioning meteorological service), which is not yet available in the Far North semiarid region of Cameroon. Thus, small-scale farmers in Zeleved and Tilde lack access to information that would allow them to respond to erratic rains and be aware of false starts.

That said, it is hard to argue a case for 'generic' adaptations being solely driven by climate factors. Glantz (1987) claims that even a perfect forecast would be of limited use unless numerous social, political, and economic barriers were removed. According to Belliveau et al (2006), one of the most important prerequisites for enhancing resilience and people's ability to implement response options, in addition to knowledge about climate science, is a clear focus on the drivers of generic vulnerability and the interconnectedness of various risks that define multiple exposure-sensitivities. In the localities of Zeleved and Tilde, what reflects most exposure-sensitivities is clearly the manifestation of social vulnerability, with people stressed by endemic and epidemic diseases, limited income-generating sources, and inadequate village infrastructure. For this reason, (Reid and Vogel, 2006) suggests that addressing the fundamental livelihood and development problems as well as strengthening social, economic, and environmental adaptive capacity will make it easier for at-risk groups to respond to climate extremes, whether they are droughts or floods.

\section{Conclusion}


This research attempts to apply a generic vulnerability framework using two contrasting ecosystems in a climate hotspot of the semi-arid far north region of Cameroon, which brings to light some of the complexities of exposure-sensitivities and adaptation faced by poor resource dependents in the context of climate change and a changing environment. The vulnerability assessment contributes to our understanding of vulnerability to climate change, which has implications for efforts and activities meant to promote effectual adaptations to future changes in the climate. It appears that vulnerability occurs because of the mix of processes and factors that shape exposure-sensitivities and resilience. The findings reveal that there are considerable constraints on the resilience of small-scale farmers, as the factors that limit their opportunities are determined beyond their level of control. The study shows that smallholder farmers are very aware of the increased climate variability as locally evidenced by worsening within-season rainfall distribution, shortening of cropping seasons, long dry spells within rainy seasons, and extreme flooding. However, the majority of farmers are most concerned about rainfall variability, erratic rains, and false starts, inter alia, as this is apparently a major constraint for farm output. Some of the assumed impacts include a drastic decline in crop yields. Also cited was the breakup of social capital as community members scatter in desperate search of alternative livelihood options. Furthermore, smallholders frequently lack timely access to sufficient quantities of high-quality agricultural inputs (primarily improved seed and fertilizers) or to appropriate agricultural technologies and institutional support that maximize yields of rice, sorghum, and millet, among others. The study reveals that low input agriculture results in soil mining and reduced fertility over time. In addition, low food and fodder yields do not sustain livestock, forcing grazing that leads to loss of manure. There is a need to acknowledge that smallholder communities in rural areas are highly vulnerable to climate change and variability, a situation that is worsened by a lack of research and extension capacity to address the emerging challenges at the grassroots level. Therefore, it is imperative to enhance the capabilities of households, communities, and relevant institutions to respond appropriately to these changing circumstances in order to reduce vulnerability and future threats to food security and environmental integrity. The issue relative to the role of institutions is more about gaining insights into how well-responding institutions grounded in a local context can be strengthened to activate and enhance the performance of internal adaptation to secure food production systems. This requires the understanding of socioeconomic implications necessary to sustain livelihoods in the context of climate variability and change. With the establishment of the Adaptation Fund and new money going to adaptation, it will be of great advantage to find ways to integrate climate change science into tertiary curricula, among others, and further enhance the various stakeholders, including communities, policy makers, and extension agencies.

\section{Declarations}

Acknowledgement: Leibniz Centre for Agricultural Landscape Research (ZALF), Sustainable Land Use in Developing Countries and a number of individuals have been instrumental in the preparation of this research sample, and although it is not possible to cite all of them, some deserve particular mention. Dr Katharina Loehr and Associate Professor Stefan Sieber for their advice and mentorship. Mr. Adam Lederer provided insightful comments and editing to improve the quality of the research sample. 
Funding: This research was supported by the Alexander von Humboldt Foundation, under the International Climate Protection Fellowship Program 2021-2022 (ICP-AvH) and the publication charge was funded by the Open Access Fund of the Leibniz Association.

Credit authorship contribution statement: Hamza Moluh Njoya; Shibire Bekele Eshetu; Haji Athumani Msangi; Herve Alain Napi Wouapi: Writing - original draft, review and editing. Writing the Methodology section and Conceptualization. Katharina Loehr and Stefan Sieber designed the study and approved the protocol and the bibliographical research. All authors read and approved the final manuscript.

Conflict of Interest: The authors declare that they have no conflict of interest.

\section{References}

1. Adger WN (2006) Vulnerability. Global Environmental Change, 16(3), 268-281. doi:https://doi.org/10.1016/j.gloenvcha.2006.02.006

2. Belliveau S, Smit B, Bradshaw B (2006) Multiple exposures and dynamic vulnerability: evidence from the grape industry in the Okanagan Valley, Canada. Global Environmental Change, 16(4), 364-378. doi:https://doi.org/10.1016/j.gloenvcha.2006.03.003

3. Carberry P, Gladwin C, Twomlow S (2004) Linking simulation modelling to participatory research in smallholder farming systems (1038-6920). http://ciatlibrary.ciat.cgiar.org/Articulos_CIAT/tsbf/pdf/nut_mgt_paper_3.pdf.

4. Cooper PJ, Dimes J, Rao K, Shapiro B, Shiferaw B, Twomlow S (2008) Coping better with current climatic variability in the rain-fed farming systems of sub-Saharan Africa: An essential first step in adapting to future climate change? Agriculture, ecosystems \& environment, 126(1-2), 24-35. doi:https://doi.org/10.1016/j.agee.2008.01.007

5. Dixon RK, Smith J, Guill S (2003) Life on the edge: vulnerability and adaptation of African ecosystems to global climate change. Mitigation and Adaptation Strategies for Global Change, 8(2), 93-113. doi:https://doi.org/10.1023/A:1026001626076

6. ECAM4 (2014) Poverty and Rural Activities. Fourth Cameroon Household Survey, Implementation Report, July 2014. https://ins-cameroun.cm/en/types-de-document/rapports/page/2/

7. Eriksen S, Schipper ELF, Scoville-Simonds M, Vincent K, Adam HN, Brooks N, Mills-Novoa M (2021). Adaptation interventions and their effect on vulnerability in developing countries: Help, hindrance or irrelevance? World development, 141, 105383. doi:https://doi.org/10.1016/j.worlddev.2020.105383

8. Glantz MH (1987) Drought in Africa. Scientific American, 256(6), 34-41. http://www.jstor.org/stable/24979400

9. Hamza MN, Engwali FD, Dinictri SWB (2019) Assessing the Food Security of Vulnerable Agricultural Households to Climate Change in the Council of Tokombéré, Far North Région of Cameroon: An Analysis Focused on the FCS, HDDS and CSI. International Journal of Agricultural Economics, 4(1), 19. doi:https://doi.org/10.11648/j.ijae.20190401.13 
10. Houssou-Goe SSP (2008) Agriculture et changement climatique au Bénin: risques climatiques, vulnérabilité et stratégies d'adaptation des populations rurales du département du Couffo (Doctoral dissertation, Département d'Économie, Socio-Anthropologie et Communication pour le développement rural (DESAC), Université d'Abomey-Calavi (UAC), Cotonou, $B J$ ). http://hdl.handle.net/10625/44965

11. IPCC (2007) Climate Change 2007: Impacts, Adaptation and Vulnerability. Contribution of Working Group II to the Fourth Assessment. Report of the Intergovernmental Panel on Climate Change. Retrieved from Cambridge, UK: https://www.ipcc.ch/report/ar4/wg2/

12. Kelly P M, Adger WN (2000) Theory and practice in assessing vulnerability to climate change and Facilitating adaptation. Climatic change, 47(4), 325-352. doi:https://doi.org/10.1023/A:1005627828199

13. Kohlbacher $F$ (2006) The use of qualitative content analysis in case study research. Forum Qualitative Sozialforschung/Forum: Qualitative Social Research, 7(1), 1-30. doi:https://doi.org/10.17169/fqs-7.1.75

14. Kotir J H (2011) Climate change and variability in Sub-Saharan Africa: a review of current and future trends and impacts on agriculture and food security. Environment, Development and Sustainability, 13(3), 587-605. doi: https://doi.org/10.1007/s10668-010-9278-0

15. MINEP (2009) Ministry of Environment and Nature Protection, Decree No. 2009/410 of 10 December 2009 to create, organize and specify modalities for the functioning of the National Observatory of climatic variability. http://www.minep.gov.cm/index.php/fr/component/content/article/66evenements/68-creationde-lobservatoire-national-des-changements-climatiques

16. Morgan DL (1996) Focus groups. Annual Review of Sociology, 22(1), 129-152. doi:https://doi.org/10.1146/annurev.soc.22.1.129

17. Morgan RPC (2009) Soil erosion and conservation: John Wiley \& Sons. https://svgaos.nl/wpcontent/uploads/2017/02/Morgan_2005_Soil_Erosion_and_Conservation.pdf

18. Reid, P., and Vogel, C. (2006). Living and responding to multiple stressors in South Africa-Glimpses from KwaZulu-Natal. Global Environmental Change, 16(2), 195-206. https://doi.org/10.1016/j.gloenvcha.2006.01.003

19. Sawadogo H (2011) Using soil and water conservation techniques to rehabilitate degraded lands in northwestern Burkina Faso. International journal of agricultural sustainability, 9(1), 120-128. https://doi.org/10.3763/ijas.2010.0552

20. Schipper E L F (2007) Climate change adaptation and development: Exploring the linkages. Tyndall Centre for Climate Change Research Working Paper, 107, 13. doi: https://citeseerx.ist.psu.edu/viewdoc/download?doi=10.1.1.501.7769\&rep=rep1\&type=pdf

21. Tidze VC, Ibrahim M, Issac T (2016) Dynamics of household energy and cooking stoves in Maroua, Far North Region of Cameroon. Journal of Scientific Research and Reports, 1-13. doi: https://doi.org/10.9734/JSRR/2016/21548 
22. Turner BL, Kasperson RE, Matson PA, McCarthy JJ, Corell RW, Christensen L, Schiller A (2003) A framework for vulnerability analysis in sustainability science. Proceedings of the national academy of sciences, 100(14), 8074-8079. https://doi.org/10.1073/pnas.1231335100

23. Turner li B (2010) Vulnerability and resilience: Coalescing or paralleling approaches for sustainability science? Global Environmental Change, 20(4), 570-576. doi: https://doi.org/10.1016/j.gloenvcha.2010.07.003

24. Washington R, Harrison M, Conway D, Black E, Challinor A, Grimes D, Todd M (2006) African climate change: taking the shorter route. Bulletin of the American Meteorological Society, 87(10), 1355-1366. doi:https://doi.org/10.1175/BAMS-87-10-1355

25. Ziervogel G, and Taylor A (2008) Feeling stressed: integrating climate adaptation with other priorities in South Africa. Environment: Science and Policy for Sustainable Development, 50(2), 32-41. doi:https://doi.org/10.3200/ENVT.50.2.32-41

\section{Figures}




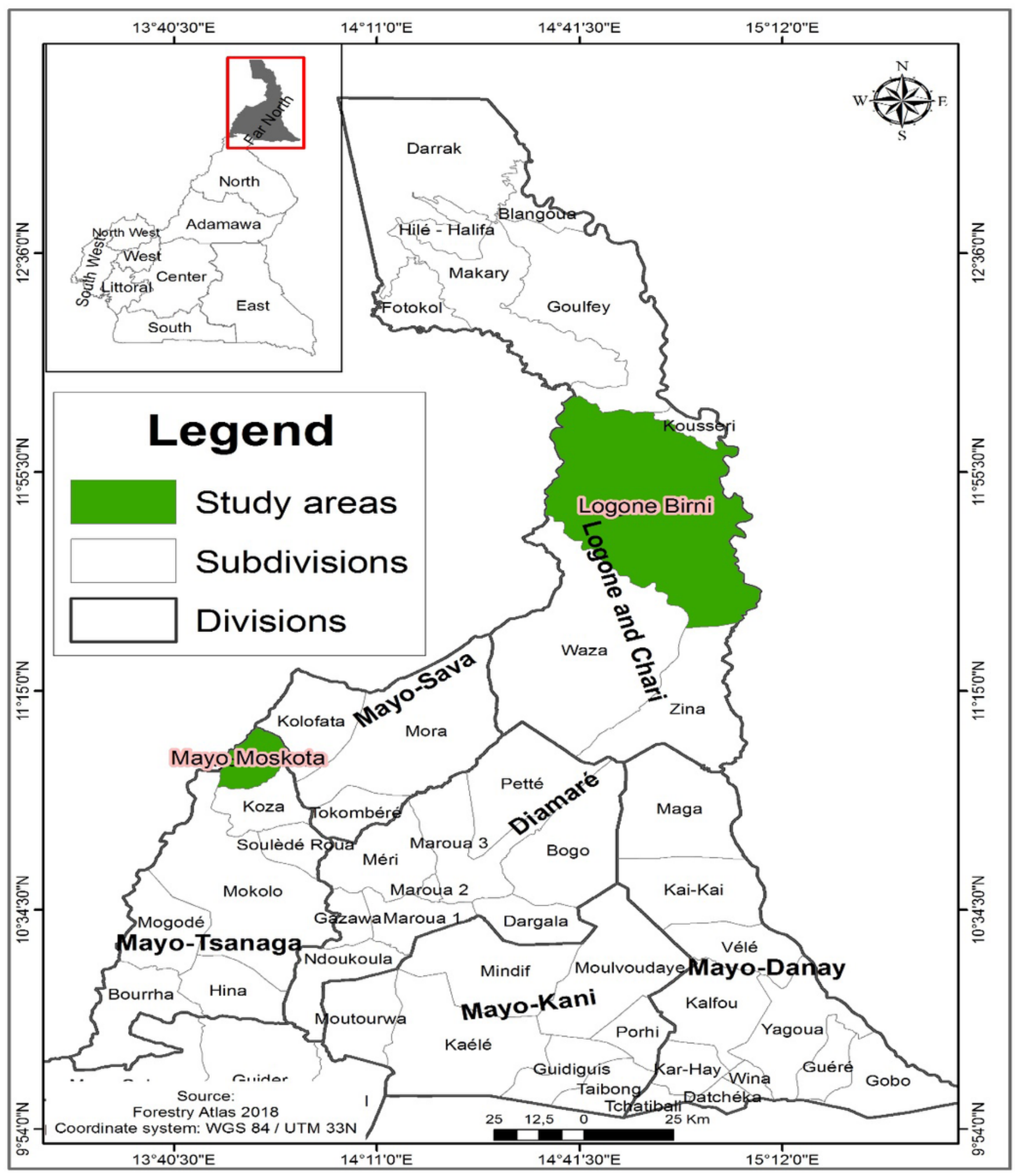

Figure 1

Geographical Location of the Study Areas (Source: Forestry Atlas 2018). 


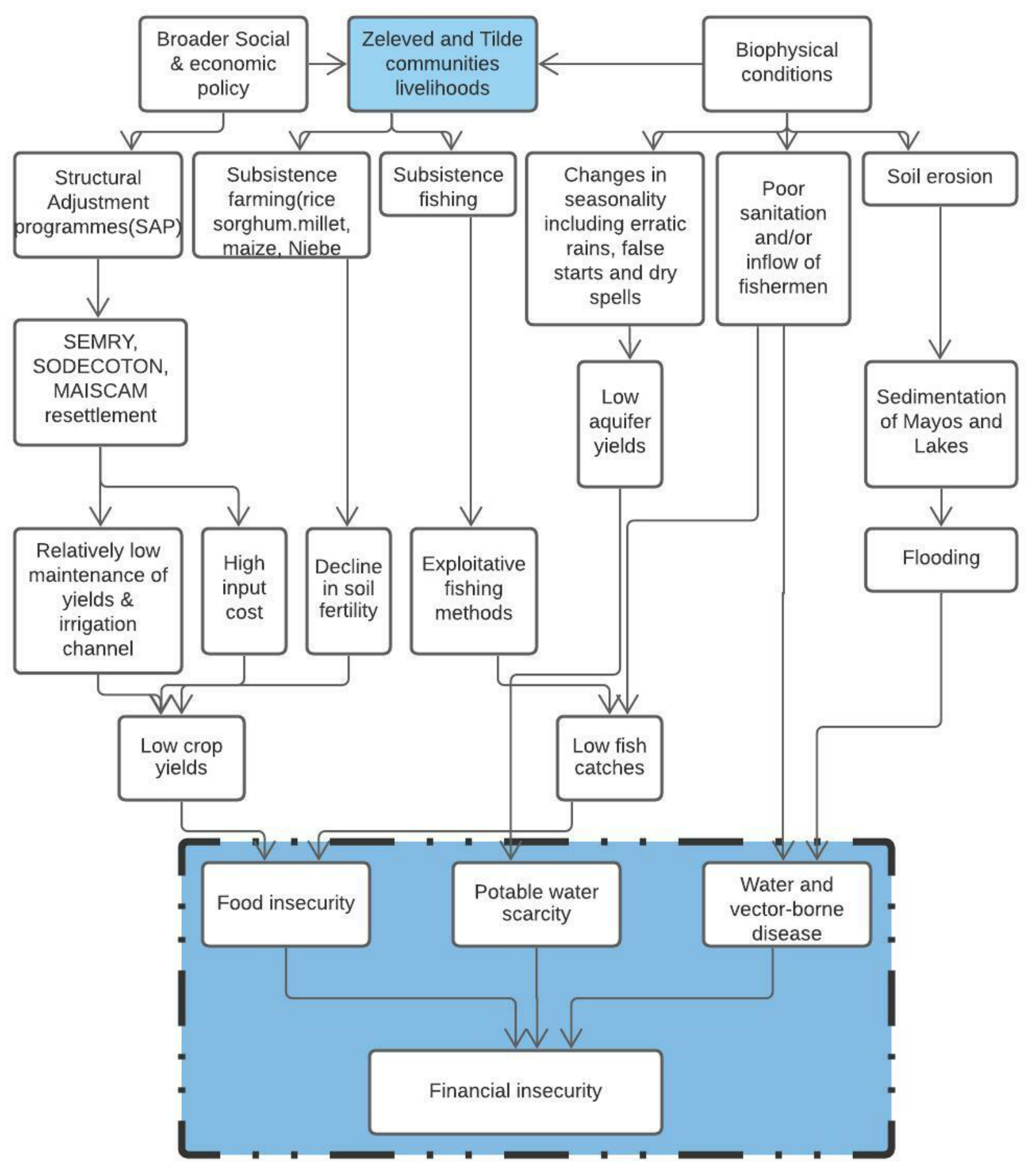

Figure 2

Processes of exposure-sensitivity in Zeleved and Tilde, Far North semiarid region of Cameroon 


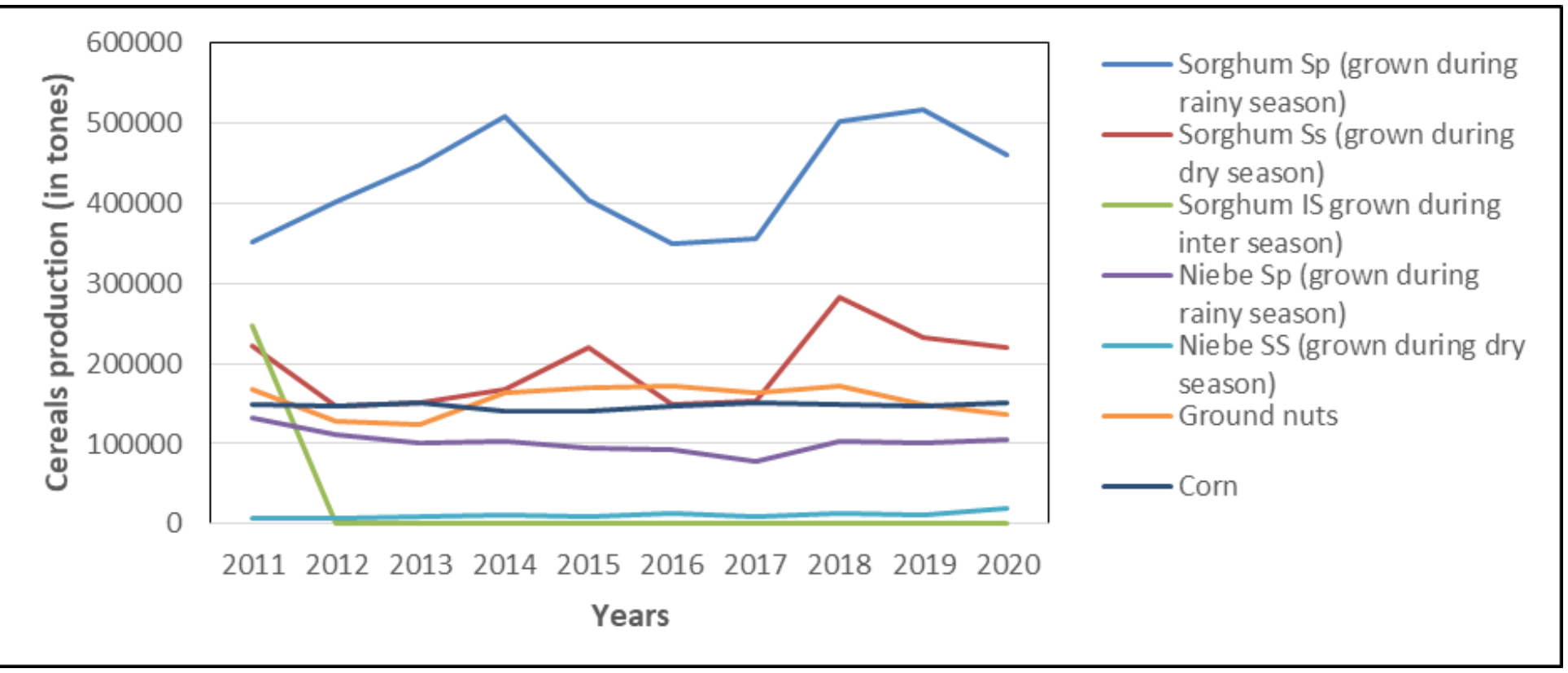

Figure 3

Trends of the cereals production in the entire Far North semiarid region of Cameroon between 2011 and 2020. (Source: Stats Far North Regional Delegation - Ministry of Agriculture and Rural Development (MINADER), 2020 annual report)

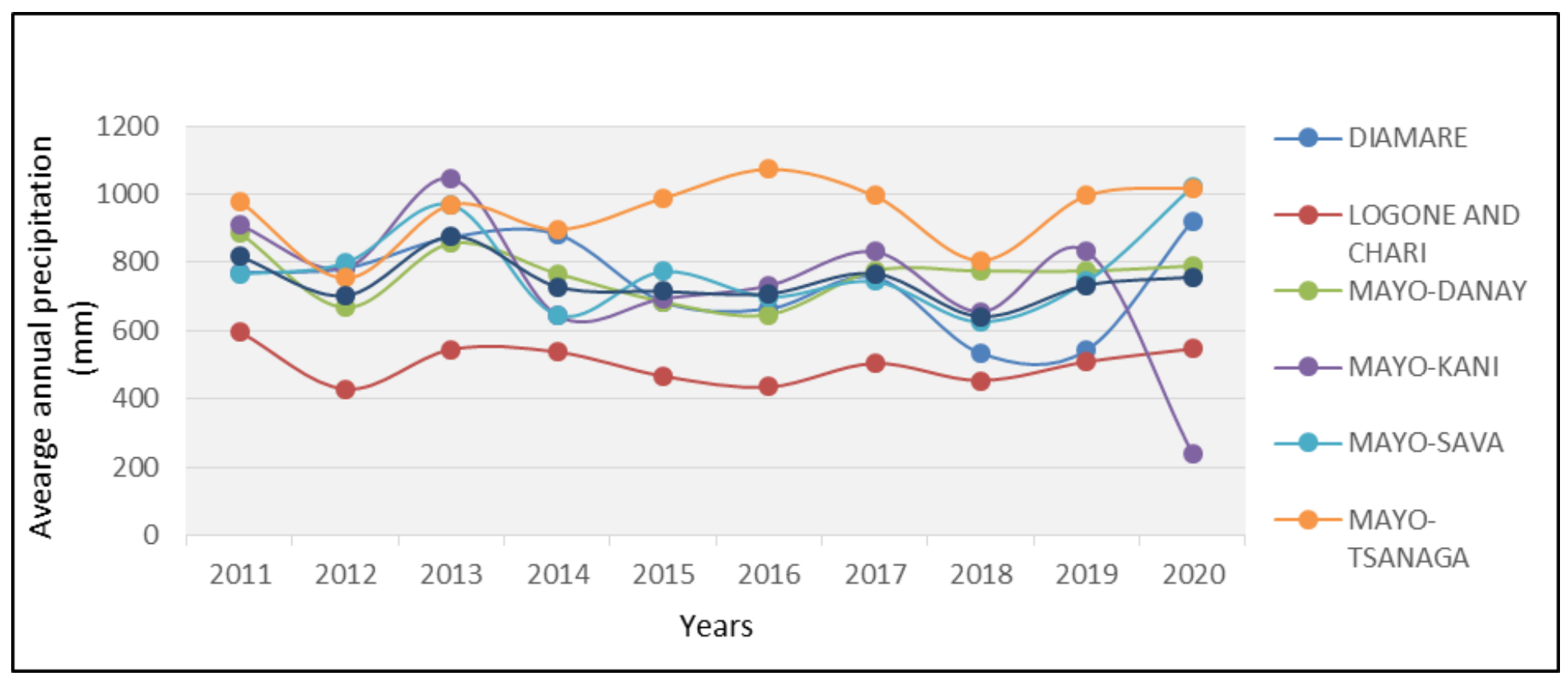

\section{Figure 4}

Inter-annual variability of precipitation in the six regions that compose the Far North region of Cameroon. (Source: Stats Far North Regional Delegation - MINADER, 2020 annual report) 

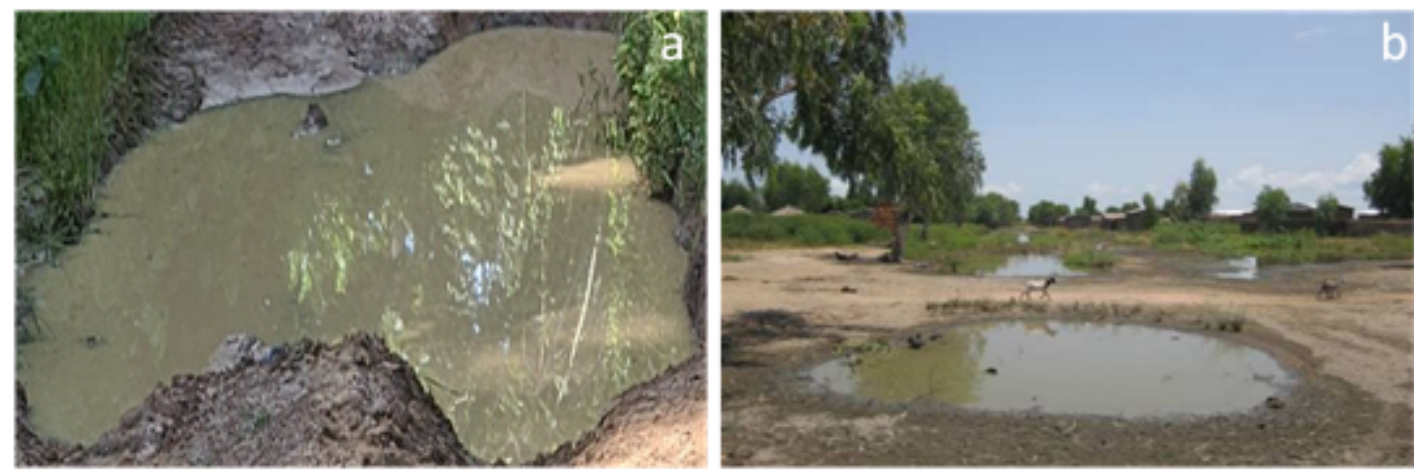

\section{Figure 5}

A partial view of Zeleved (a) and Tilde (b), an area full of swamps and prone to both water and vectorborne disease. (Source: Authors)
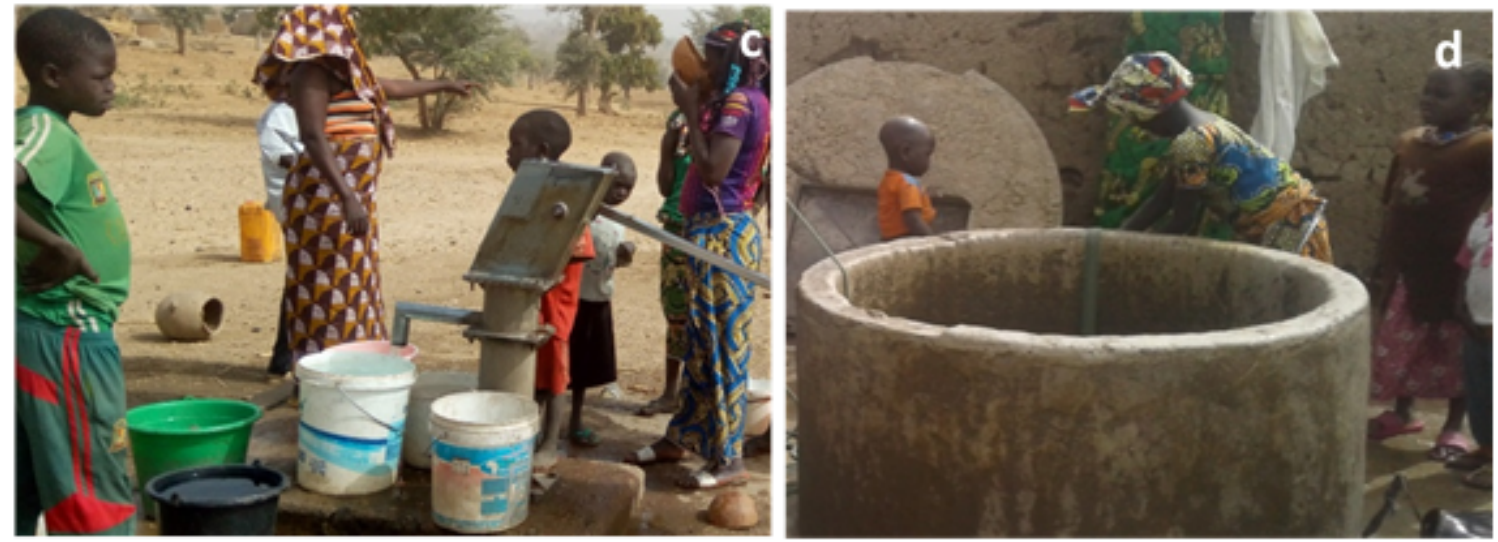

\section{Figure 6}

One of the very few wells in service in Zeleved (c) and Tilde (d)

Worse, the inflow of approximately 4,000 nomadic fishermen (coming from Nigeria, Chad Republic, Cameroon, and Niger) during the high fishing season further contributes to making cholera an endemic disease. The fact that the latter remain along the border of artificial Lake Maga during the four-month authorised fishing season of March-June without adequate housing and sanitation facilities is a risk factor for the spread of cholera. 

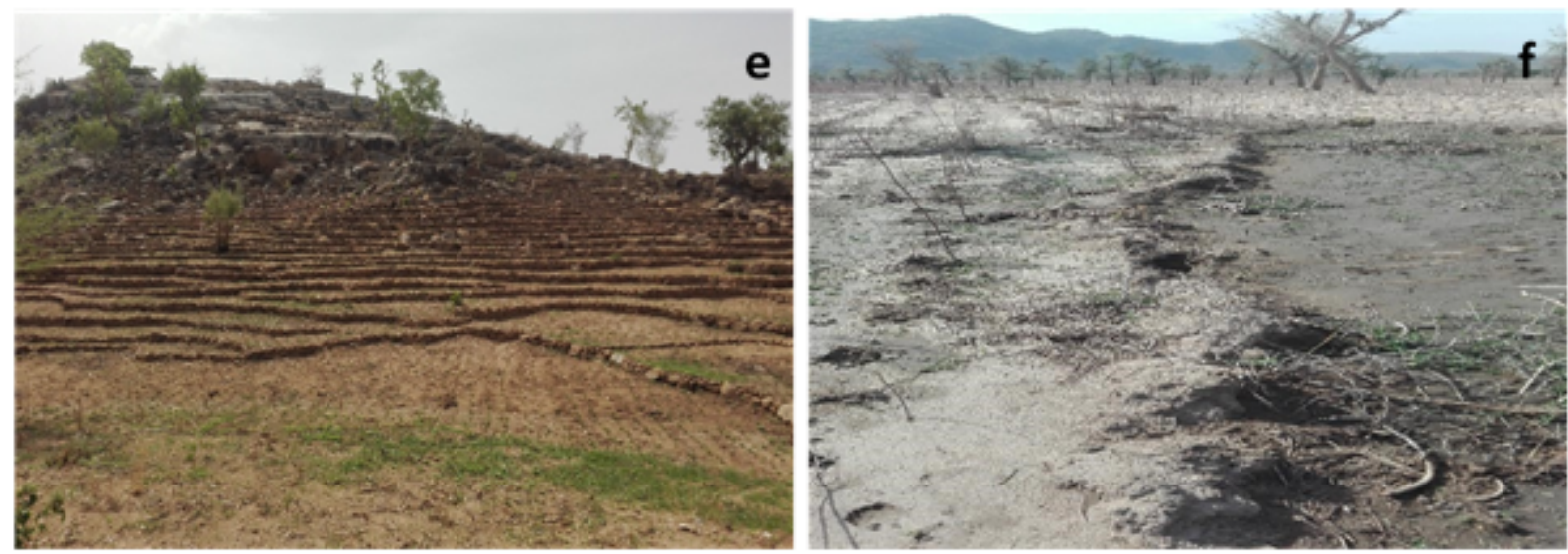

Figure 7

view from a terrace (e) and bund (f) in Zeleved (Source: Authors)
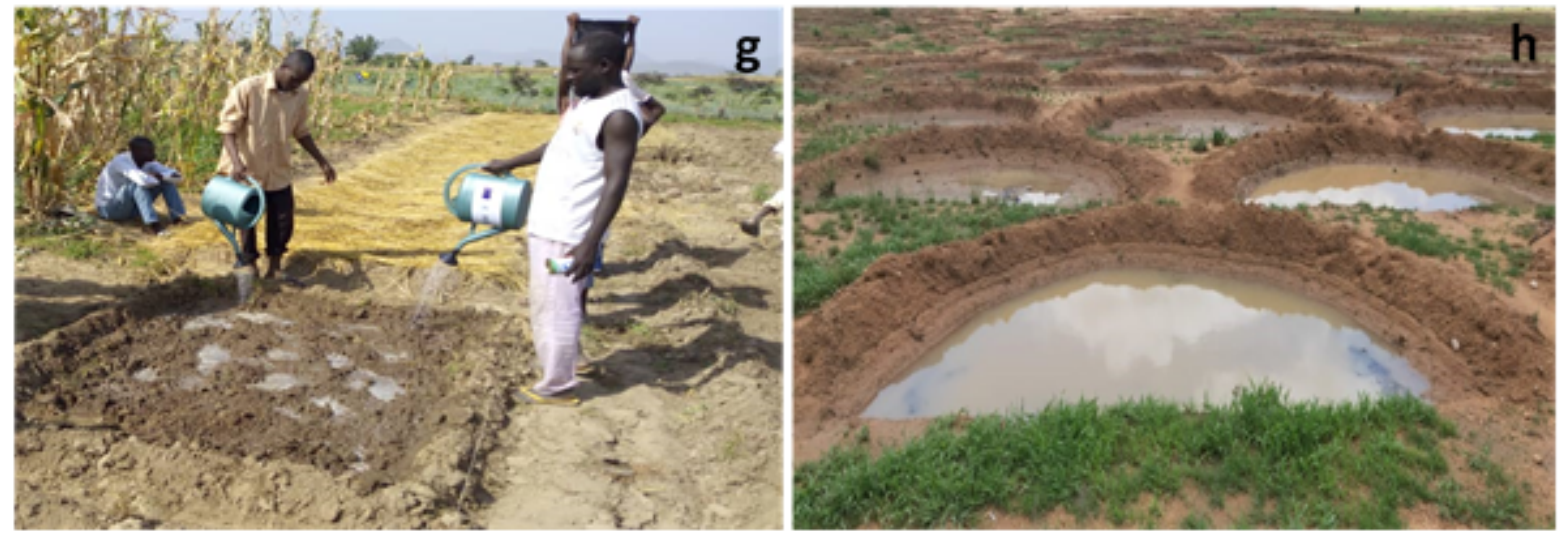

\section{Figure 8}

View of a (g) plank and (h) half-moon in Tilde (Source: Authors) 

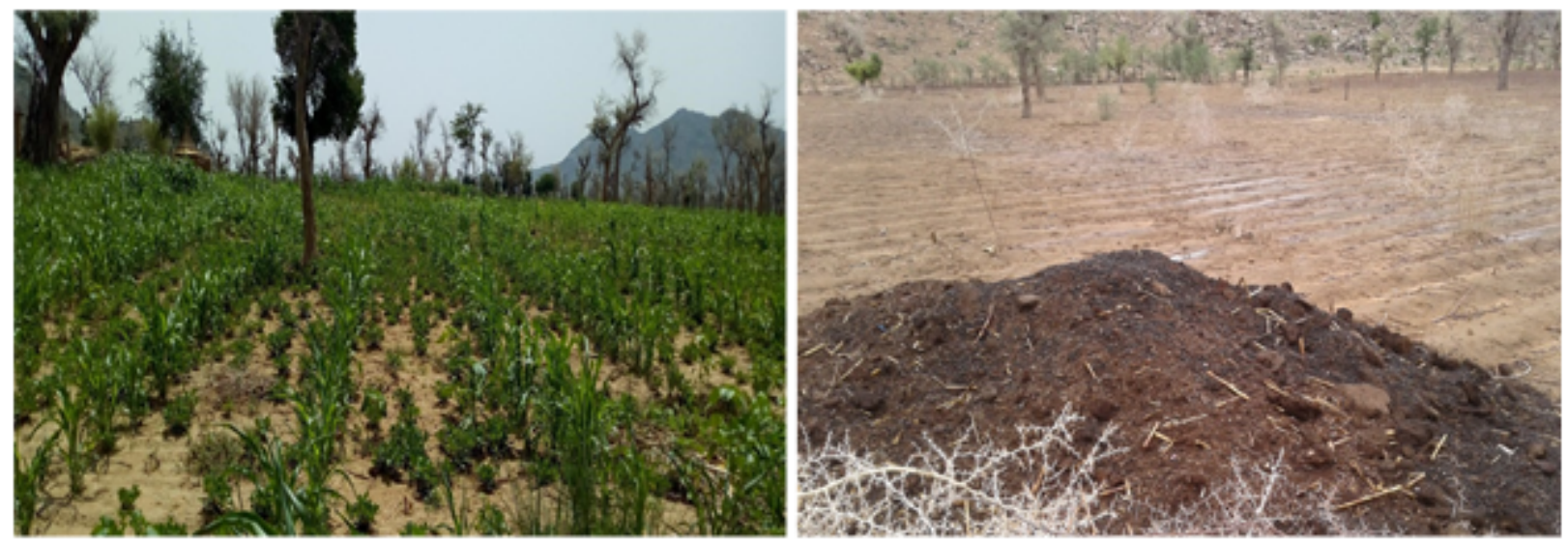

Figure 9

View of (i) crop association and (j) use of livestock waste in Tilde (Source: Authors) 